\title{
Description of a new goatfish species, Upeneus randalli n. sp. (Mullidae), from the Persian Gulf, with remarks and identification keys for the genus Upeneus
}

\author{
FRANZ UIBLEIN ${ }^{1,2}$ and PHILLIP C. HEEMSTRA ${ }^{2}$ \\ ${ }^{1}$ Institute of Marine Research, Nordnesgaten 33, 5817 Bergen, Norway. E-mail: franz@imr.no \\ ${ }^{2}$ South African Institute of Aquatic Biodiversity, Private Bag 1015, Grahamstown, South Africa.
}

\begin{abstract}
SUMMARY: The number of species of the goatfish genus Upeneus from the western Indian Ocean has increased considerably due to recent taxonomic efforts. Here we describe a new species, Upeneus randalli $\mathrm{n}$. sp., based on body and fin coloration and 50 morphometric and meristic characters of eight specimens from the Persian Gulf, and supported by comparative data from a taxonomic review of western Indian Ocean Upeneus species and additional material from collections. Upeneus randalli is distinguished from congeners by the combination of 8 dorsal-fin spines, 14 pectoral-fin rays, 23 to 25 gill rakers, 28 to 30 lateral-line scales, pectoral-fin width 22 to 26 times in SL, and red bars on both caudal-fin lobes. We provide two identification keys: one key is for distinguishing among four species groups and the morphologically unique $U$. filifer, accounting for all 28 species of the genus, and the other key is for the six closely related species of the "U. tragula group" from the western Indian Ocean, including $U$. randalli $n$. sp. Since the colour patterns fade away soon after collection and can be completely lost during preservation, morphometric and meristic characters are important for correctly identifying $U$. randalli n. sp. and the closely related $U$. margarethae. The latter species shows considerable variation in body form in different areas of the western Indian Ocean. We discuss the significance of detailed comparative studies of caudal-fin colour patterns and body-form characters for obtaining a deeper understanding of inter- and intraspecific diversity among Upeneus.
\end{abstract}

Keywords: body form, colour patterns, goatfishes, Mullidae, new species, population differences, taxonomy, Upeneus.

RESUMEN: Descripción de una nueva especie de SAlmonete, Upeneus randalli N. SP. (Mullidae), Del golfo PÉRSICO, CON DISCUSIÓN Y CLAVES DE IDENTIFICACIÓN DEL GÉNERO UPENEUS. - El número de especies de salmonetes del género Upeneus del Océano Índico Occidental ha aumentado considerablemente debido a los recientes trabajos taxonómicos. En este trabajo se describe una nueva especie, Upeneus randalli $\mathrm{n}$. sp., en base a la coloración del cuerpo y las aletas y a 51 caracteres morfométricos y merísticos de ocho especímenes del golfo Pérsico, apoyados por datos comparativos de una revisión taxonómica de las especies del océano Índico occidental Upeneus y material adicional de colección. Upeneus randalli es differenciada de sus congeners por la combinación de 8 espinas en la aleta dorsal, 14 radios en la aleta pectoral, 23-25 branquiespinas, 28-30 escamas en la línea lateral, anchura de la aleta pectoral 22-26 veces en LS y barras rojas en ambos lóbulos de la aleta caudal. Se proporcionan dos claves de identificación, una para la distinción entre cuatro grupos de especies y la especie $U$. filifer, morfológicamente única, que responde por el total de las 28 especies del género y la otra clave para las seis especies estrechamente relacionadas del "grupo U. tragula" del océano Índico occidental incluyendo U. randalli $\mathrm{n}$. sp. A causa de que los patrones de color se desvanecen pronto después de la recolección y que pueden perderse completamente durante la conservación, los caracteres morfométricos y merísticos son importantes para la correcta identificación de $U$. randalli $\mathrm{n}$. sp. y la especie estrechamente relacionada $U$. margarethae. Esta última muestra una considerable variación en la forma del cuerpo entre diferentes áreas del océano Índico occidental. En este trabajo se discute si la correlación de estudios comparativos detallados de patrones de color de la aleta caudal y forma del cuerpo es significativa para mejorar el conocimiento de la diversidad inter- e intraespecífica entre Upeneus.

Palabras clave: forma del cuerpo, patrones de color, salmonetes, Mullidae, nueva especie, diferencias poblacionales, taxonomía, Upeneus. 


\section{INTRODUCTION}

The number of known goatfish species (Mullidae) has dramatically increased due to recent taxonomic efforts that have targeted the coastal fish diversity of the western Indian Ocean (Randall and Heemstra, 2009; Randall and King, 2009; Uiblein and Heemstra, 2010; Uiblein and Heemstra 2011). For instance, in a review of the genus Upeneus from this area a total of 16 species were reported (Uiblein and Heemstra, 2010), which represents an increase in the number of species of over $40 \%$ compared to an earlier account by Kumaran and Randall (1984), who only listed nine species.

The widest ranging species among the four new Upeneus species described in the review (Uiblein and Heemstra, 2010), U. margarethae, has been reported to occur along the East African coast and Madagascar, in the Red Sea, the Persian Gulf, off Sri Lanka, off NW Australia, and in the Arafura Sea (W-Pacific). Since no documentation of fresh colour was available from other areas and comparisons indicated geographic variation in body form, Uiblein and Heemstra (2010) recognized the main distribution area of this species to be between Mozambique, Somalia and Madagascar, where morphological variation appeared to be rather low among the localities from which the type specimens originated.

Shortly after publication of the review, additional specimens of Upeneus from the Persian Gulf were found at the Bishop Museum, Hawaii. Among this material were seven specimens of a small Upeneus species with eight dorsal spines, which appeared to be closely related to the single specimen of U. margarethae from the Persian Gulf that had been included in the review. However, examination of colour photographs of two specimens from the Bishop Museum collection suggested that they were significantly different to $U$. margarethae, and therefore detailed taxonomic studies would be necessary.

Here we report the results of the examination of 50 morphometric and meristic characters and the colour patterns of the eight Persian Gulf specimens. A new species, Upeneus randalli $\mathrm{n}$. sp., is described and compared with closely related species from the western Indian Ocean using published data and new results obtained from three Bishop Museum specimens of $U$. margarethae originating from Mafia Island, Tanzania, and Kerala, SW India. An updated diagnosis for $U$. margarethae is provided to account for changes in several morphometric and meristic characters due to the exclusion/inclusion of study material and to facilitate direct comparison with the closely related $U$. randalli $\mathrm{n} . \mathrm{sp}$.

We provide two identification keys based on published data of 25 additional species (Uiblein and Heemstra 2010; Uiblein and Heemstra 2011) and new data gathered from 6 Pacific U. filifer (Ogilby, 1910) during a visit to the Australian Museum: a key for distinguishing among four species groups of Upeneus and the morphologically unique $U$. filifer, and a key for the "U. tragula group" from the western Indian Ocean, which consists of $U$. randalli $\mathrm{n}$. sp. and five other closely related species. In addition, we further examine the morphological variation among western Indian Ocean U. margarethae populations.

\section{MATERIALS AND METHODS}

Abbreviations and descriptions of 50 characters are provided in Table 1. The data of 252 specimens of 24 Upeneus species published in the review by Uiblein and Heemstra (2010) were used for preparing the keys and species comparisons. Additional material for $U$. filifer and U. margarethae that was examined for this study is listed below. Data from Uiblein and Heemstra (2011) were also included.

For the intraspecific comparison among Upeneus margarethae, Principal Component Analysis (PCA) with size-adjustment based on the residuals obtained from log-log regressions of the morphometric variables with standard length, was used to obtain information on optimal distinction (Uiblein and Winkler, 1994).

Comparative material examined: Upeneus filifer: E-Australia: AMS 32120-003, $83 \mathrm{~mm}$, New South Wales, off Clarence River, $2^{\circ} 20^{\prime}$ 'S, $153^{\circ} 34^{\prime} \mathrm{E}$, FRV Kapala, prawn trawl, 67-73 m; AMS 32196-001, 4: 68$82 \mathrm{~mm}$, New South Wales, off Clarence River, $29^{\circ} 25^{\prime} \mathrm{S}$, $153^{\circ} 34^{\prime}$ E, FRV Kapala, prawn trawl, 65-70 m.

Upeneus margarethae. Tanzania: BPBM33441, 100 mm, Mafia Island, Mafia Channel, 10-50 m; SWIndia: BPBM27694, 71-82 mm, Kerala State, Vizhinjam, fishing harbour.

Scientific institutions with abbreviations of fish collections: Australian Museum, Sydney (AMS), Bishop Museum, Honolulu (BPBM), Zoological Museum, University of Copenhagen (ZMUC).

\section{RESULTS}

\author{
Family Mullidae \\ Genus Upeneus Cuvier, 1829
}

Upeneus Cuvier, 1829: 157. Type species Mullus vittatus (Forsskål, 1775) by subsequent designation of Desmarest (1856).

Diagnosis. Dorsal fins VII or VIII+9; anal fin I, 6; pelvic fins I, 5; pectoral-fin rays 12-17; principal caudal-fin rays $7+8$ (median 13 branched); gill rakers 4-9+14-24=18-33; lateral-line scales 28-39, lateral line complete; small scales present basally on second dorsal, anal and caudal fins; small teeth present on vomer, palatines and jaws, multiserial and villiform on jaws; body oblong, slightly compressed; barbel length in adults 4-7 times in SL, snout length 7-11 times in SL, sub-equal to postorbital length (7-10 times in SL); in fresh fish lateral body stripes and/or caudal-fin bars of differing colours, dark caudal-fin bars frequently retained on preserved fish. 
TABLE 1. - Abbreviation and description of morphometric and meristic characters

Morphometric characters

\begin{tabular}{|c|c|}
\hline SL & standard length, distance between snout tip and caudal fin base at mid-body \\
\hline BODYDD & body depth at first dorsal-fin origin \\
\hline BODYDA & body depth at anal-fin origin \\
\hline HALFDD & half body depth (from lateral line downwards) at first dorsal fin origin \\
\hline HALFDA & half body depth (from lateral line downwards) at anal fin origin \\
\hline CPDD & caudal-peduncle depth, minimum depth anterior to caudal dorsal origin \\
\hline CPDW & caudal-peduncle width at position of CPDD measurement \\
\hline HEAD1 & maximum head depth, vertical distance at ventral edge of operculum \\
\hline HEAD2 & head depth across a vertical midline through eye \\
\hline SUBORB & suborbital depth - distance between lower edge of orbit to ventral midline of head \\
\hline INTORB & interorbital length - least distance between upper bony edges of orbits \\
\hline HEADL & head length - distance between snout tip to posteriormost margin of operculum \\
\hline SNOUTL & snout length -distance between snout tip to anterior margin of orbit \\
\hline PORBL & postorbital length, distance between posterior edge of orbit and posterior margin of operculum \\
\hline ORBITL & orbit length, horizontal fleshy orbit diameter \\
\hline ORBITD & orbit depth, vertical fleshy orbit diameter \\
\hline UJAWL & upper-jaw length - distance between symphysis and posterior end of upper jaw \\
\hline LJAWL & lower-jaw length - distance between symphysis of lower jaw and posterior end of upper jaw \\
\hline SNOUTW & snout width - least distance between hinder margins of upper jaw, with closed mouth \\
\hline BARBL & barbel length \\
\hline BARBW & maximum barbel width, horizontal width measured at base of soft part of barbel \\
\hline SD1 & first pre-dorsal length - distance between snout tip to origin of first dorsal fin \\
\hline SD2 & second pre-dorsal length - distance between snout tip to origin of second dorsal fin \\
\hline D1D2 & interdorsal distance - distance between last spine of first dorsal and first ray of second dorsal fin \\
\hline CPDL & caudal-peduncle length - distance between last anal ray and ventral origin of caudal fin \\
\hline SANL & pre-anal length - distance between snout tip to origin of anal fin \\
\hline SPEL & pre-pelvic length - distance between snout tip to origin of pelvic fin \\
\hline SPEC & pre-pectoral length - distance between snout tip to dorsal origin of pectoral fin \\
\hline D2ANL & second dorsal-fin depth - distance between origin of second dorsal fin to origin of anal fin \\
\hline D1PELV & pelvic-fin depth - distance between origin of first dorsal fin to origin of pelvic fin \\
\hline D1PEC & pectoral-fin depth - distance between origin of first dorsal fin to dorsal origin of pectoral fin \\
\hline D1B & length of first dorsal-fin base \\
\hline D2B & length of second dorsal-fin base \\
\hline CAUH & distance between dorsal caudal-fin origin and upper caudal-lobe tip \\
\hline ANALB & length of anal-fin base \\
\hline ANALH & distance between anal-fin origin and anal-fin anterior tip ( $=$ to tip of first anal ray) \\
\hline PELVL & distance between pelvic-fin origin and pelvic-fin tip \\
\hline PECTL & distance between pectoral-fin dorsal origin and pectoral-fin tip \\
\hline PECTW & width of pectoral-fin base \\
\hline $\mathrm{D} 1 \mathrm{H}$ & $\begin{array}{l}\text { first dorsal-fin height - distance between first dorsal-fin origin and first dorsal-fin anterior tip (= to tip of first long } \\
\text { dorsal-fin spine) }\end{array}$ \\
\hline $\mathrm{D} 2 \mathrm{H}$ & $\begin{array}{l}\text { second dorsal-fin height - distance between second dorsal-fin origin and second dorsal-fin anterior tip (= to tip of } \\
\text { second dorsal-fin ray) }\end{array}$ \\
\hline
\end{tabular}

Meristic and colour characters

\begin{tabular}{ll}
\hline P & pectoral-fin rays \\
GrUud & rudimentary (= width larger than its depth) gill rakers on upper limb \\
GrUd & developed gill rakers on upper limb \\
GrLd & rudimentoped gill rakers on lower limb (including gill raker in corner) \\
GrLud & total gill rakers on upper limb \\
GrU & total gill rakers on lower limb \\
$\mathrm{GrL}$ & total gill rakers \\
$\mathrm{Gr}$ & scales along lateral line to caudal-fin base (excluding scales on caudal fin) \\
LLscal &
\end{tabular}

Distribution. In all major oceans, tropical to subtropical, only a single species in the Atlantic and two in the Mediterranean, both so-called "Lessepsian" immigrants from the Red Sea after the opening of the Suez Canal (Ben Tuvia 1966).

Remarks. Here we recognize 28 species as valid, 18 of which occur in the western Indian Ocean: seven species, Upeneus davidaromi Golani, 2001, U. doriae (Günther, 1869), U. indicus Uiblein and Heemstra, 2010, U. oligospilus Lachner, 1954, U. randalli n. sp., U. seychellensis Uiblein and Heemstra, 2011, and U. suahelicus Uiblein and Heemstra, 2010, are restricted to the western Indian Ocean; two species, U. mascareinsis Fourmanoir and Guézé, 1967 and $U$. supravittatus Uiblein and Heemstra, 2010, occur in the Indian Ocean; eight species, U. guttatus (Day, 1868), U. margarethae Uiblein and Heemstra, 2010, U. moluccensis (Bleeker, 1855), U. sulphureus Cuvier, 1829, U. sundaicus (Bleeker, 1855), U. taeniopterus Cuvier in Cuvier and Valenciennes, 1829, U. tragula Richardson, 1846, and U. vittatus (Forsskål, 1775) occur in the Indo-Pacific; and one species, U. pori BenTuvia and Golani, 1989) is found in the western Indian 
Ocean and-together with U. moluccensis - the Mediterranean (Uiblein and Heemstra 2010).

Of the ten additional species, two, $U$. australiae Kim and Nakaya, 2002, and U. quadrilineatus Cheng and Wang, 1963, occur in the eastern Indian Ocean and the west Pacific; four species $U$. asymmetricus Lachner, 1954, U. japonicus (Houttuyn, 1782), U. luzonius Jordan and Seale, 1907, and U. subvittatus (Temminck and Schlegel, 1843) occur in the west Pacific; three species U. filifer (Ogilby, 1910), U. francisi Randall and Guézé, 1992, and U. mouthami Randall and Kulbicki, 2006 occur in the western central and/or southwest Pacific: and one, U. parvus Poey, 1852, occurs in the western Atlantic.

A single species, U. xanthogrammus Gilbert, 1892, has been described from the east Pacific; however, no material was available for our taxonomic studies. There have been many misidentifications in this genus and the validity status of this species is still unclear to us.

\section{Key to Upeneus species groups}

In Upeneus one single species and four species groups can be distinguished from each other based on a small set of characters that includes the number of dorsal spines and gill rakers, the length of the longest dorsal-fin spine, the length of pelvic and pectoral fins, and the presence or absence of caudal-fin bars and mid-lateral body stripes (Uiblein and Hemstra, 2010; Uiblein and Heemstra, 2011).

1a. Longest spine of first dorsal fin 2.5 times or less in SL, no caudal-fin bars or mid-lateral body stripes . U. filifer

1b. Longest dorsal-fin spine more than 3 times in SL; caudal-fin bars and/or mid-lateral body stripes present in fresh fish 2

2a. Dorsal-fin spines 7, first 2 spines usually longest; total gill rakers 21-32; pectoral-fin rays 13-15; bars on upper caudal-fin lobe of fresh fish of all species; bars on lower caudal-fin lobe in some species U. japonicus group

(U. asymmetricus, U. australiae, U. francisi, U. guttatus, U.japonicus, U. pori, U. seychellensis)

2b. Dorsal-fin spines 8 , first spine minute, recumbent, partly hidden by skin and scales at fin origin; total gill rakers 18-33; pectoral-fin rays 13-17; bars on caudal fin of fresh fish of several species.....

3a. Total gill rakers 18-26; pectoral-fin rays 13-15; pelvic-fin length $0.8-1.1$ times in pectoral fins; bars on caudal fin in fresh fish of all species; bars retained or not retained in preserved fish ...U. tragula group (U. luzonius, $U$. margarethae, $U$. oligospilus, $U$. randalli n. sp., U. sundaicus, U. taeniopterus, U. tragula, U. mouthami) 3b. Total gill rakers 25-33; pectoral-fin rays 14-17; pelvic-fin length 1.1-1.5 times in pectoral fins; bars on caudal fin in fresh fish of several species; bars retained in preserved fish.

4a. No bars on lower caudal-fin lobe; bars on upper caudal-fin lobe in some species; bars retained in preserved fish. U. moluccensis group (U. doriae, U. moluccensis, U. quadrilineatus, U. sulphureus)

4b. Bars on both caudal-fin lobes in fresh and preserved fish $U$. vittatus group (U. davidaromi, U. indicus, U. mascareinsis, U. parvus, U. suahelicus, $U$. subvittatus, U. supravittatus, $U$. vittatus)

\section{Key to western Indian Ocean species of the tragula group}

1a. Dark dots or blotches on body and paired fins; first dorsal-fin tip dark; one brown to black mid-lateral body stripe in fresh and preserved fish; barbels yellow in fresh fish; upper-jaw length 7.1-9.2 times in $\mathrm{SL}$

1b. No dark dots or blotches on body and paired fins (except for area of lateral line in $U$. randalli $\mathrm{n}$. sp. in life); no dark dorsal-fin tip; 0-2 yellowish or pale brown lateral body stripes on fresh fish; barbels white or yellow in fresh fish; upper-jaw length 7.910 times in SL

2a. Total number of caudal-fin bars 6-9 (6 or fewer in juveniles $<7 \mathrm{~cm} \mathrm{SL}$ ), 3-4 bars on lower caudal-fin lobe; caudal-fin length 3.6-4.1 times in SL and 1.01.3 times in head length; pelvic-fin length 4.7-6.0 times in SL (Persian Gulf) ............... U. oligospilus

2b. Total number caudal-fin bars 10 or more (7-10 in juveniles $<7 \mathrm{~cm} \mathrm{SL}$ ), 4-7 bars on lower caudal-fin lobe; caudal-fin length 3.1-3.6 times in SL and 0.91.1 times in head length; pelvic-fin length 4.2-5.0 times in SL (Indo-Pacific) ................... U. tragula

3a. Pectoral-fin length 5.0-5.8 times in SL; lateral-line scales 35-39; upper caudal-fin lobe with 4-8 dark bars, well retained on preserved fish; fresh fish with a pale brown mid-lateral body stripe and a weaker, more yellowish stripe below (Indo-Pacific)

U. taeniopterus

3b. Pectoral-fin length 4.0-4.9 times in SL; lateral-line scales 28-34; upper caudal-fin lobe with 4-6 red or grey bars, not or only traces retained on preserved fish; fresh fish with or without a yellow or pale brown mid-lateral body stripe ......................... 4

4a. Total gill rakers 18-21; lateral-line scales 31-34; first dorsal-fin height 3.4-4.1 times in SL; caudalpeduncle depth 7.9-8.7 times in SL; barbels frequently yellow in fresh fish; 5-6 red or grey bars on upper caudal-fin lobe in fresh fish (Indo-Pacific) ... 
U. sundaicus

4b. Total gill rakers 21-25; lateral-line scales 28-30; first dorsal-fin height 4.3-5.3 times in SL; caudalpeduncle depth 9.0-10 times in SL; barbels white; 4-5 red bars on upper caudal-fin lobe in fresh fish, 3-4 distally from fork .. 5

5a. Total gill rakers 21-24; caudal-peduncle width 17-28 times in SL and 4.9-7.9 in head length; anal-fin base 7.2-9.9 times in SL; pectoral-fin width 17-23 times in SL and 4.9-6.5 in head length; usually 4 red bars on upper caudal-fin lobe in fresh fish, 3 distally from fork; broad red band on lower caudal-fin lobe, covering up to 5 or 6 red bars, the latter only partly visible along ventral fin margin in fresh fish; mid-lateral body stripe running through eye, red from snout tip to eye and yellow from behind eye to caudal-fin base; stripe absent in preserved fish (Indian Ocean and Arafura Sea) ...................... U. margarethae

5b. Total gill rakers 23-25; caudal-peduncle width 27 34 times in SL and 7.5-10 in head length; anal-fin base 8.9-11 times in SL; pectoral-fin width 22-26 times in SL and 6.3-7.6 in head length; 5 red bars on upper caudal-fin lobe in fresh fish, 4 distally from fork; lower caudal-fin lobe with up to 8 dark red bars, bars not covered by a band; mid-lateral body stripe only vaguely visible in fresh fish; stripe absent in preserved fish (Persian Gulf) U. randalli $\mathrm{n} . \mathrm{sp}$.

\section{Upeneus randalli $\mathrm{n} . \mathrm{sp}$.}

(Figs. 1-2, Table 2)

U. margarethae: non Uiblein and Heemstra, 2010 (pp. 44-46, one specimen from Persian Gulf)

Holotype: BPBM 33180, $101 \mathrm{~mm}$, Persian Gulf, Kuwait, off southern Kuwait, $29^{\circ} 00^{\prime}$ N $48^{\circ} 25^{\prime}$ E, 15 - 20 m, R/V Bahith, trawl, col lected by James Bishop, 20th August 1985.

Paratypes: Persian Gulf: BPBM 21201, 6: 66-88 mm, Bahrain, fish market; ZMUC P49161, 105 mm.

Diagnosis. Dorsal fins VIII+9; pectoral-fin rays 14; gill rakers 6-7+17-19=23-25; lateral-line scales 28-30; measurements in \% SL: body depth at first dorsal-fin origin 23-24; body depth at anus 19-22; caudal-peduncle depth 9.9-11; caudal-peduncle width 2.9-3.8; maximum head depth 19-21; head depth through eye 15-16; head length 27-30; orbit length 6.2-7.4; upper jaw length 10-11; barbel length 16-20; caudal-fin length 27-30; anal-fin base 9.4-11; anal-fin height 1519; pelvic-fin length 20-22; pectoral-fin length 20-22; pectoral-fin width 3.8-4.4; first dorsal-fin height 19-22; second dorsal-fin height 16-20; total bars on caudal fin 11-13, with 5 red bars on upper caudal-fin lobe, 4 on lobe itself and one at lobe base; 6-8 red bars on lower caudal-fin lobe; caudal-fin bars not retained on preserved fish, apart from some traces of bars mostly on lower lobe and dark pigmentation at lower lobe tip; 3 horizontal series of black dots mid-laterally, 3-4 dots below posterior part of first dorsal-fin base, 2 below anterior part of second dorsal-fin base, and 2 behind second dorsal-fin base, dots not retained in preserved material; first dorsal fin pale with some reddish pigment anteriorly and dorsally; second dorsal fin, pelvic and anal fins with reddish stripes; fin colour not retained in preserved fish; barbels white; body and head reddish marbled; ventral side of head and belly white; body uniformly pale brown in preserved fish, sometimes darker dorsally, with vague brown band mid-laterally.

Description. Measurements in \% SL and counts are given in Table 2; morphometric data as ratios of SL for holotype, data for paratypes in brackets: body elongate, body depth at first dorsal-fin origin 4.1 [4.2-4.4] longer than pectoral-fin (4.7 [4.6-4.9], body depth at anal-fin origin 4.6 [4.8-5.4], caudal-peduncle depth 9.5 [9.410], much larger than orbit length (15 [13-16]), head depth across eye 6.5 [6.1-6.6], head length 3.5 [3.3-3.7] larger than maximum depth of body and subequal to caudal-fin length (3.6 [3.3-3.7]), pelvic-fin length 4.7 [4.5-5.0] subequal to length of pectoral fins, pectoralfin width 25 [22-26], second dorsal-fin length 6.1 [5.16.3] similar to barbel length (5.7 [4.9-6.1]).

Fresh colour (Fig. 1). Head and body white laterally, with some irregular red markings forming marblelike pattern; ventral part of head and belly white; tip of snout and upper jaw beige; iris red; weakly indicated mid-lateral beige stripe from eye to caudal-fin base running anteriorly below lateral line and posteriorly along or slightly above lateral line; stripe overlain by 3 horizontal series of black dots mid-laterally, 4 dots below rear part of first dorsal-fin base, 2 below anterior part of second dorsal-fin base, and 2 behind second dorsal fin base; the latter associated with dark pigmentation dorsally, forming saddle immediately behind second dorsal fin; dorsal fins pale, the first with some red markings anteriorly and dorsally, the second with one or 2 sub-horizontal red stripes; pectoral fins hyaline; pelvic and anal fins pale, pectoral fins with 4 dusky-red stripes; anal fin with 2 dusky stripes; caudalfin upper lobe hyaline, with 4 red bars on lobe itself (one at lobe tip) and $5^{\text {th }}$ faint bar at the base of lobe; bar width less than width of pale interspaces between bars; lower lobe pale-reddish with 7 dark red bars, one bar at tip; bar width similar to width of pale interspaces (in the photographed paratype (Fig. 1), this pattern is less evident, as bars seem to be connected with each other, but see also Remarks section); barbels white.

Preserved colour. Head and body pale beige to pale brown; body of holotype becoming darker dorsally, with broad brown mid-lateral band from behind operculum to caudal-fin base; head and operculum of holotype with whitish patches; holotype and several paratypes show dark saddle behind second dorsal fin that reaches to lateral line; all fins transparent and without pigment, except for some remains of bars 


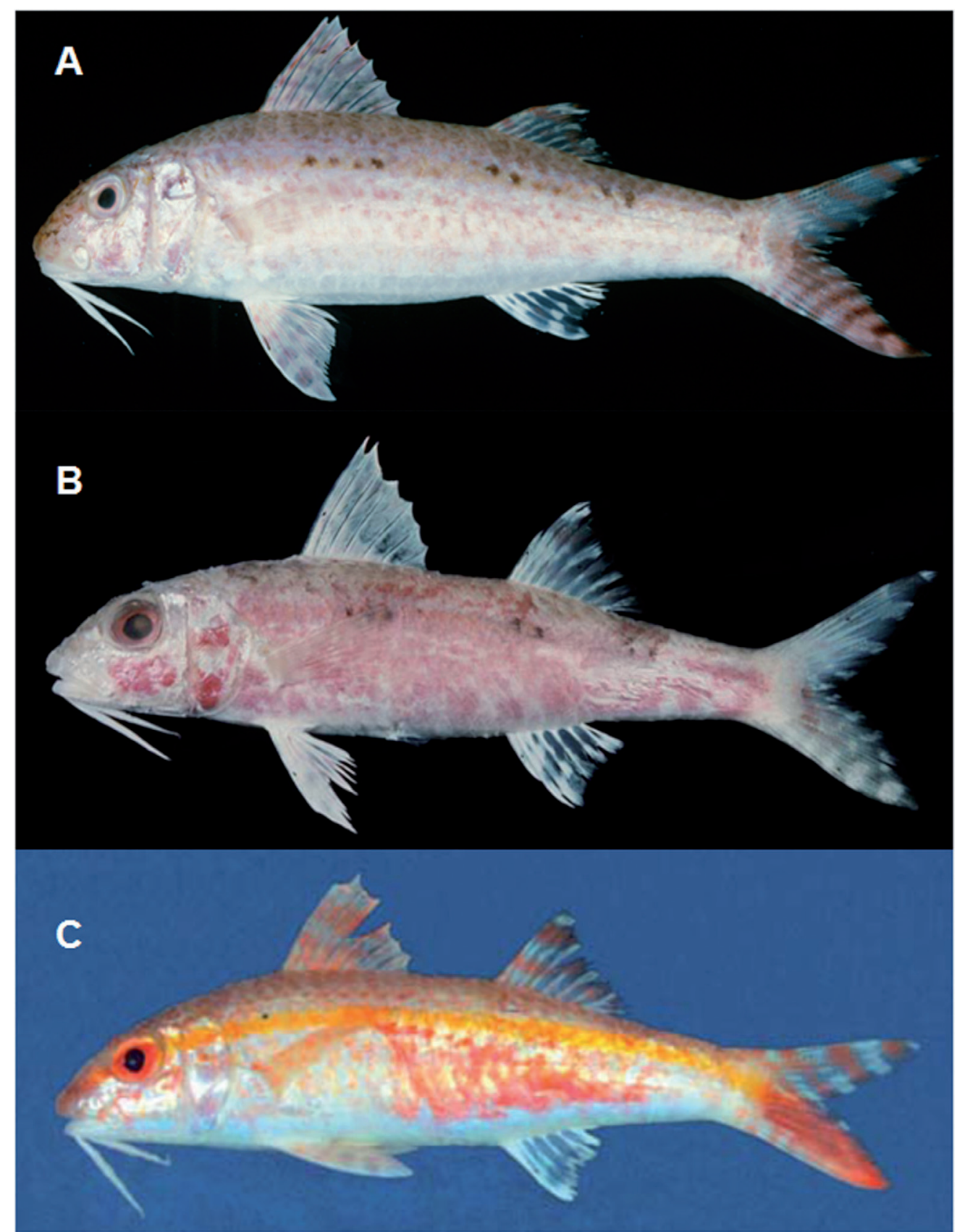

FIG. 1. - A: Upeneus randalli n. sp., holotype, BPBM 33180, SL 100 mm, Kuwait (J.E. Randall); B: Upeneus randalli n. sp., paratype, BPBM 21201, SL 80 mm, Bahrain (J.E. Randall); C: Upeneus margarethae, holotype, SAIAB 82217, SL 82 mm, Mozambique (P.C. Heemstra).

on caudal fin including dark pigmentation on tip of lower caudal-fin lobe of holotype and a few paratypes; holotype shows no bars on upper caudal-fin lobe and remains of 6 distal-most bars on lower caudal-fin lobe, with dark pigmentation retained on inner dorsal half of lower lobe and on tip; lateral line distinct, extending to or slightly beyond caudal-fin base.

\section{Distribution. Persian Gulf.}

Etymology. The name of this species "randalli" is in honour of the esteemed ichthyologist John E. "Jack"
Randall who collected six of the seven paratypes, transferred the holotype to the Bishop Museum collection and took a photograph of the fresh holotype used for the colour description.

Remarks. Upeneus randalli n. sp. differs from the other western Indian Ocean species of the tragula group as follows (cf. Table 2, Figs. 1, 2; Uiblein and Heemstra 2010): from $U$. margarethae in more total gill rakers (23-25 vs. 21-24), narrower caudal peduncle width (2.93.8 vs. $3.6-5.7 \%$ SL), more slender head depth across eye (15-16 vs. 15-18), smaller orbit (length: 6.2-7.4 
TABLE 2. - Measurements (in \% SL) and counts for Upeneus randalli n. sp. and U. margarethae of the Western Indian Ocean. Characters showing deviations from Uiblein and Heemstra (2010) are indicated in bold.

\begin{tabular}{|c|c|c|c|c|c|c|c|c|c|c|c|c|c|c|c|c|c|}
\hline & \multirow{3}{*}{ HT } & \multicolumn{5}{|c|}{ Upeneus randalli $\mathrm{n}$. $\mathrm{sp}$. } & \multicolumn{11}{|c|}{ Upeneus margarethae } \\
\hline & & \multicolumn{2}{|c|}{7 Paratypes } & \multicolumn{3}{|c|}{$\begin{array}{c}\text { All Types } \\
(\mathrm{n}=8)\end{array}$} & \multicolumn{2}{|c|}{$\begin{array}{c}\text { All Types } \\
(\mathrm{n}=21)\end{array}$} & \multirow[t]{2}{*}{$\begin{array}{l}\text { Mafia } \\
\text { Island }\end{array}$} & \multicolumn{2}{|c|}{$\begin{array}{l}\text { Red Sea } \\
(n=2)\end{array}$} & \multicolumn{2}{|c|}{$\begin{array}{l}\text { S-India, } \\
\text { Sri Lanka }(n=4)\end{array}$} & \multicolumn{4}{|c|}{$\begin{array}{c}\text { All Western Indian Ocean } \\
\text { specimens }\end{array}$} \\
\hline & & Min & Max & Min & Mean & Max & Min & Max & & Min & Max & Min & Max & Min & Mean & Max & \\
\hline $\mathrm{SL}(\mathrm{mm})$ & 101 & 66 & 106 & 66 & 84.3 & 106 & 67 & 124 & 100 & 93 & 94 & 71 & 82 & 67 & 88.9 & 124 & \\
\hline BODYDD & 24 & 23 & 24 & 23 & 23.5 & 24 & 22 & 26 & 25 & 25 & 25 & 23 & 24 & 22 & 24.6 & 26 & \\
\hline BODYDA & 22 & 19 & 21 & 19 & 20.2 & 22 & 20 & 24 & 21 & 23 & 23 & 20 & 22 & 20 & 21.3 & 24 & \\
\hline HALFDD & 20 & 19 & 20 & 19 & 19.6 & 20 & 18 & 22 & 20 & 21 & 21 & 18 & 20 & 18 & 20.2 & 22 & \\
\hline HALFDA & 17 & 15 & 16 & 15 & 15.7 & 17 & 15 & 19 & 15 & 16 & 16 & 15 & 15 & 15 & 16.3 & 19 & \\
\hline CPDD & 11 & 9.9 & 11 & 9.9 & 10.3 & 11 & 10 & $11 *$ & 9.9 & 11 & 11 & 10 & 10 & 9.9 & 10.5 & 11 & \\
\hline CPDW & 3.8 & 2.9 & 3.5 & 2.9 & 3.4 & 3.8 & 4.0 & $5.7^{*}$ & 3.6 & 4.3 & 4.3 & 3.6 & 4.1 & 3.6 & 4.6 & 5.7 & \\
\hline HEAD1 & 21 & 19 & 21 & 19 & 20.3 & 21 & 19 & 23 & 21 & 21 & 22 & 20 & 20 & 19 & 21 & 23 & \\
\hline HEAD2 & 16 & 15 & 16 & 15 & 15.6 & 16 & 15 & 18 & 17 & 17 & 18 & 16 & 16 & 15 & 17 & 18 & \\
\hline SUPORB & 9.5 & 8.0 & 10.1 & 8.0 & 9.1 & 10 & 9.1 & 12 & 9.7 & 12 & 12 & 9.1 & 9.3 & 9.1 & 10.2 & 12 & \\
\hline INTORB & 8.2 & 7.2 & 8.8 & 7.2 & 8.0 & 8.8 & 7.3 & 9.1 & 8.5 & 8.4 & 8.9 & 7.5 & 8.2 & 7.3 & 8.1 & 9.1 & \\
\hline HEADL & 28 & 27 & 30 & 27 & 28.8 & 30 & 27 & 31 & 28 & 28 & 30 & 28 & 29 & 27 & 28.7 & 31 & \\
\hline SNOUTL & 11 & 11 & 12 & 11 & 11.3 & 12 & 11 & 12 & 11 & 11 & 11 & 10 & 11 & 10 & 11.2 & 12 & \\
\hline PORBL & 11 & 10 & 12 & 10 & 11.1 & 12 & 11 & 12 & 11 & 12 & 12 & 11 & 12 & 11 & 11.5 & 12 & \\
\hline ORBITL & 6.9 & 6.2 & 7.4 & 6.2 & 6.9 & 7.4 & 6.6 & 9.1 & 7.4 & 7.7 & 8.1 & 7.1 & 8.1 & 6.6 & 8.0 & 9.1 & \\
\hline ORBITD & 6.2 & 5.1 & 6.4 & 5.1 & 5.9 & 6.4 & 5.5 & $8.0 *$ & 6.6 & 6.4 & 6.4 & 5.7 & 6.5 & 5.5 & 6.8 & 8.0 & \\
\hline UJAWL & 11 & 10 & 11 & 10 & 10.9 & 11 & 10 & 12 & 10 & 10 & 11 & 11 & 12 & 10 & 11.0 & 12 & \\
\hline LJAWL & 10 & 9.1 & 10 & 9.1 & 10.0 & 10 & 9.1 & 11 & 10 & 9.5 & 9.5 & 10 & 11 & 9.1 & 10.2 & 11 & \\
\hline SNOUTW & 8.5 & 7.8 & 9.0 & 7.8 & 8.4 & 9.0 & 9.0 & 11 & 9.1 & - & - & 8.1 & 8.3 & 8.1 & 9.6 & 11 & \\
\hline BARBL & 17 & 16 & 20 & 16 & 18.2 & 20 & 16 & 20 & 18 & 16 & 18 & 17 & 17 & 16 & 17.6 & 20 & \\
\hline BARBW & 0.7 & 0.6 & 0.7 & 0.6 & 0.7 & 0.7 & 0.7 & 1.2 & 0.7 & 0.9 & 0.9 & 0.7 & 0.9 & 0.7 & 0.8 & 1.2 & \\
\hline SD1 & 36 & 34 & 38 & 34 & 36.6 & 38 & 35 & 40 & 37 & 35 & 37 & 36 & 36 & 35 & 36.8 & 40 & \\
\hline SD2 & 64 & 61 & 66 & 61 & 64.2 & 66 & 60 & 67 & 65 & 62 & 63 & 62 & 65 & 60 & 63.1 & 67 & \\
\hline D1D2 & 15 & 13 & 15 & 13 & 14.4 & 15 & 11 & 16 & 16 & 12 & 14 & 13 & 15 & 11 & 13.7 & 16 & \\
\hline CPDL & 23 & 23 & 25 & 23 & 23.6 & 25 & 22 & 26 & 23 & 22 & 25 & 24 & 25 & 22 & 24.1 & 26 & \\
\hline SANL & 63 & 63 & 67 & 63 & 64.6 & 67 & 61 & 68 & 64 & 67 & 70 & 63 & 64 & 61 & 64.3 & 70 & \\
\hline SPEL & 31 & 31 & 34 & 31 & 32.0 & 34 & 28 & 34 & 30 & 34 & 34 & 30 & 31 & 28 & 30.7 & 34 & \\
\hline SPEC & 29 & 29 & 32 & 29 & 30.5 & 32 & 28 & 32 & 29 & 31 & 33 & 29 & 30 & 28 & 30.1 & 33 & \\
\hline D2ANL & 22 & 19 & 21 & 19 & 20.7 & 22 & 20 & 24 & 21 & 23 & 24 & 21 & 23 & 20 & 21.8 & 24 & \\
\hline D1PELV & 24 & 23 & 24 & 23 & 23.4 & 24 & 22 & 26 & 25 & 25 & 25 & 23 & 24 & 22 & 24.5 & 26 & \\
\hline D1PEC & 17 & 15 & 17 & 15 & 16.0 & 17 & 15 & 18 & 18 & 16 & 17 & 16 & 16 & 15 & 16.8 & 18 & \\
\hline D1B & 15 & 15 & 16 & 15 & 15.2 & 16 & 15 & 18 & 16 & 14 & 16 & 14 & 16 & 14 & 15.6 & 18 & \\
\hline D2B & 14 & 12 & 15 & 12 & 13.6 & 15 & 12 & 16 & 13 & 14 & 14 & 13 & 13 & 12 & 13.9 & 16 & \\
\hline CAUH & 28 & 27 & 30 & 27 & 28.3 & 30 & 27 & 31 & 29 & 28 & 31 & 27 & 28 & 27 & 28.8 & 31 & \\
\hline ANALB & 11 & 9.4 & 11 & 9.4 & 10.2 & 11 & 10 & 14 & 11 & 11 & 12 & 11 & 12 & 10 & 12.0 & 14 & \\
\hline ANALH & 15 & 15 & 19 & 15 & 16.7 & 19 & 14 & 18 & 16 & 14 & 16 & 15 & 18 & 14 & 16.3 & 18 & \\
\hline PELVL & 21 & 20 & 22 & 20 & 21.2 & 22 & 20 & 24 & 20 & 23 & 23 & 21 & 22 & 20 & 21.9 & 24 & \\
\hline PECTL & 21 & 20 & 22 & 20 & 21.1 & 22 & 21 & 25 & 22 & 22 & 23 & 21 & 22 & 21 & 22.4 & 25 & \\
\hline PECTW & 4.0 & 3.8 & 4.4 & 3.8 & 4.1 & 4.4 & 4.4 & 5.8 & 4.4 & 4.8 & 5.1 & 4.5 & 4.8 & 4.4 & 4.9 & 5.8 & \\
\hline $\mathrm{D} 1 \mathrm{H}$ & 19 & 19 & 22 & 19 & 20.7 & 22 & 20 & 23 & 20 & 20 & 22 & 20 & 21 & 20 & 21.2 & 23 & \\
\hline $\mathrm{D} 2 \mathrm{H}$ & 16 & 16 & 20 & 16 & 17.6 & 20 & 16 & 20 & 17 & 17 & 18 & 16 & 19 & 16 & 17.6 & 20 & \\
\hline $\mathrm{P}$ & 14 & 14 & 14 & 14 & 14.0 & 14 & 13 & 14 & 14 & 14 & 14 & 14 & 14 & 13 & 13.9 & 14 & \\
\hline GrUud & 3 & 2 & 3 & 2 & 2.9 & 3 & 2 & 4 & 3 & 2 & 2 & 3 & 5 & 2 & 3.1 & 5 & \\
\hline GrUd & 3 & 3 & 4 & 3 & 3.3 & 4 & 2 & 3 & 2 & 3 & 3 & 2 & 2 & 2 & 2.6 & 3 & \\
\hline GrLd & 13 & 12 & 15 & 12 & 13.5 & 15 & 11 & 13 & 12 & 12 & 13 & 11 & 12 & 11 & 12.3 & 13 & \\
\hline GrLud & 5 & 4 & 6 & 4 & 4.6 & 6 & 4 & 6 & 5 & 4 & 5 & 4 & 5 & 4 & 4.5 & 6 & \\
\hline $\mathrm{GrU}$ & 6 & 6 & 7 & 6 & 6.1 & 7 & 5 & 7 & 5 & 5 & 5 & 6 & 7 & 5 & 5.7 & 7 & \\
\hline GrL & 18 & 17 & 19 & 17 & 18.1 & 19 & 16 & 18 & 17 & 17 & 17 & 16 & 16 & 16 & 16.8 & 18 & \\
\hline Gr total & 24 & 23 & 25 & 23 & 24.3 & 25 & 21 & 24 & 22 & 22 & 22 & 22 & 23 & 21 & 22.5 & 24 & \\
\hline Llscales & 30 & 28 & 30 & 28 & 29.1 & 30 & 28 & $30 * *$ & 30 & 29 & 30 & 29 & 29 & 28 & 29.2 & 30 & \\
\hline
\end{tabular}

$* \mathrm{n}=20 ; * * \mathrm{n}=18$

vs. 6.6-9.1; depth: 5.1-6.4 vs. 5.5-8.0), narrower snout (7.9-9.0 vs. 8.1-11), thinner barbels (0.6-0.7 vs. 0.7-1.2), shorter anal-fin base (9.4-11 vs. 10-14), shorter pectoralfin length (20-22 vs. 21-25), narrower pectoral-fin width (3.8-4.4 vs. 4.4-5.8\% SL), no conspicuous mid-lateral stripe, 4 vs. usually 3 red bars on upper caudal fin lobe behind fork, and bars on lower caudal-fin lobe not overlain with a broad red band in fresh fish; from $U$. oligospilus in more total gill rakers (23-25 vs. 20-24), shallower suborbital depth (8.0-10 vs. 9.6-12\% SL), shorter head (27-30 vs. 29-32), shorter snout (11-12 vs. 12-14), shorter postorbital length (10-12 vs. 12-13), nar- rower snout (7.8-9.0 vs. 9.8-12), longer caudal fin (2730 vs. $24-28 \%$ SL), 11-13 red vs. 6-9 brown or black bars on caudal fin, bars not or incompletely retained on preserved fish, body and fins lacking dark blotches or dots, first and second dorsal-fin tips pale in both fresh and preserved fish, mid-lateral body stripe only weakly developed in fresh fish and not retained on preserved fish, and barbels white vs. yellow in fresh fish; it differs from $U$. sundaicus in more total gill rakers (23-25 vs. 18-21), fewer lateral-line scales (28-30 vs. 31-34), less body depth (at dorsal origin: 23-24 vs. 25-28\% SL; at anal origin: $19-22$ vs. 22-24; half depth at dorsal 
origin: $19-20$ vs. 20-22), less peduncle depth (9.9-11 vs. 11-13), shallower head (maximum head depth: 1921 vs. $21-23$; head depth across eye: $15-16$ vs. 17-20; suborbital depth: 8.0-10 vs. 11-14), shorter snout (11-12 vs. 12-14), shorter jaws (upper jaw length: 10-11 vs. 11-12; lower jaw length: 9.1-10 vs. 10-12), narrower snout (7.8-9.0 vs. 11-12), shorter anal-fin base (9.4-11 vs. 11-14), smaller first dorsal fin height (19-22 vs. 25-29\% SL), presence of bars on lower caudal-fin lobe and mid-lateral body stripe only weakly developed in fresh fish, and barbels white vs. yellow (colour patterns apply to fresh fish only); from $U$. taeniopterus it differs in more total gill rakers (23-25 vs. 21-23); fewer lateral-line scales (28-30 vs. 35-39), larger orbit (orbit length: 6.2-7.4 vs. 4.4-6.3\% SL; orbit depth: 5.16.4 vs. 3.7-5.6), shorter jaws (upper jaw length: 10-11 vs. 11-13; lower jaw length: 9.1-10 vs. 9.9-12), narrower snout (7.8-9.0 vs. 9.3-11), longer first dorsal-fin base (15-16 vs. 12-15), longer paired fins (pelvic-fin length: $20-22$ vs. $18-20$; pectoral-fin length: $20-22$ vs. $17-20)$, higher second dorsal fin (16-20 vs. $14-16 \%$ SL), caudal-fin bars not or incompletely retained on preserved fish, and mid-lateral body stripe only weakly developed in fresh fish; and from U. tragula it differs in more pectoral fin rays (14 vs. mostly 13 (in 13 of 16 fish)), more total gill rakers (23-25 vs. 19-24), shorter jaws (upper jaw length: 10-11 vs. 11-14\% SL; lower jaw length: 9.1-10 vs. 11-13), longer caudal peduncle (23-25 vs. 21-24), smaller first dorsal fin height (19-22 vs. $21-24 \%$ SL), red vs. brown or black bars on caudal fin, bars not or incompletely retained on preserved fish, body and fins lacking dark blotches or dots, first and second dorsal-fin tips pale, mid-lateral body stripe only weakly developed in fresh fish and not retained in preserved fish, and barbels white vs. yellow in fresh fish.

Non-western Indian Ocean species of the tragula group (cf. Table 2, Fig. 1; Uiblein and Heemstra, 2010): Upeneus randalli $\mathrm{n}$. sp. differs from $U$. luzonius in more gill rakers (23-25 vs. 18-20), fewer lateral-line scales (28-30 vs. 31-32), half body at dorsal fin origin shallower (19-20 vs. $20-21 \%$ SL), half body at anal-fin origin deeper (15-17 vs. 13-15), less caudal-peduncle depth (9.9-11 vs. 11-13), less head depth across eye (15-16 vs. 16-18), less suborbital depth (8.0-10 vs. 10-12), shorter upper jaw (10-11 vs. 11-12), narrower snout (7.8-9.0 vs. 9.3-9.8), and smaller first dorsal-fin height (16-20 vs. 21-24); from U. mouthami it differs in pectoral-fin rays (14 vs. 13), less head depth across eye (15-16 vs. $17-18 \%$ SL), less suborbital depth (8.010 vs. $10-11$ ), smaller orbit (length: 6.2-7.4 vs. 7.8-8.3; depth: 5.1-6.4 vs. 6.6-7.0), narrower snout (7.8-9.0 vs. 11-12), shorter barbels (16-20 vs. 20-21), thinner barbels (0.6-0.7 vs. 0.9-1.4), longer caudal peduncle (23-25 vs. 21-23), longer first dorsal-fin base (15-16 vs. 11-13), shorter anal-fin base (9.4-11 vs. 11-13), shorter paired fins (pelvic fin length: 20-22 vs. 22-23; pectoral-fin length: $20-22$ vs. $22-23 \%$ SL), no well-developed mid-lateral body stripe, and white vs. yellow barbels in fresh fish.
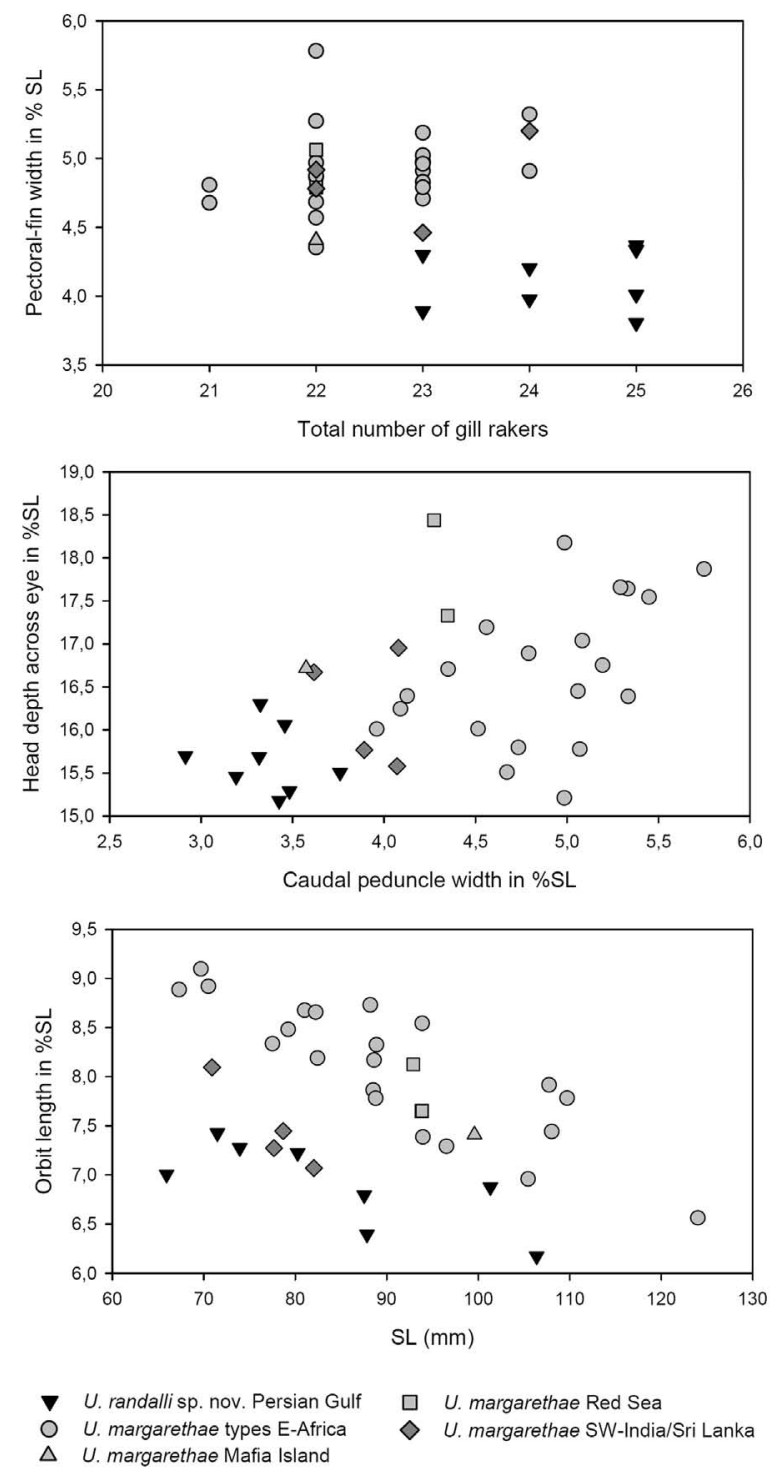

FIG. 2. - Pectoral-fin width against gill-raker number (on top), head depth through eye against caudal-peduncle width (below), and orbit length against SL (on bottom) in Upeneus randalli $\mathrm{n}$. $\mathrm{sp}$. from the Persian Gulf and U. margarethae from the western Indian Ocean.

The photographed paratype deviates considerably in body and fin colour from the holotype (see Fig. 1). This colour difference may (at least partly) derive from different post mortem treatment. Dead goatfishes with a pale body colour frequently turn red if exposed to air for a longer period of time. The tail pigmentation in red-barred goatfishes may also fade quickly after death. Upeneus randalli attains $11 \mathrm{~cm}$ SL; depth $20 \mathrm{~m}$.

Upeneus margarethae Uiblein and Heemstra, 2010 (Fig. 1-3, Table 2)

Upeneus margarethae: Uiblein and Heemstra, 2010 (pp. 44-46, Tables 3, 5; Plates 1, 3, type locality Mozambique).

$U$. bensasi (Temminck and Schlegel 1843): Bauchot and Bianchi,. 1984, in part; Fischer et al., 1990, 155, in part. 
Diagnosis. Dorsal fins VIII+9; pectoral-fin rays 13-14, mostly 14 (in 26 of 28 individuals); gill rakers 5-7+16-18=21-24; lateral-line scales 28-30; measurements in \% SL: body depth at first dorsal-fin origin 22-26; body depth at anus 20-24; peduncle depth 9.911; peduncle width 3.6-5.7; maximum head depth 1923; head depth through eye 15-18; head length 27-31; orbit length 6.6-9.1; upper jaw length 10-12; barbel length 16-20; caudal-fin length 27-31; anal-fin base 10-14; anal-fin height 14-18; pelvic-fin length 20-24; pectoral-fin length 21-25; pectoral-fin width 4.4-5.8; first dorsal-fin height 20-23; second dorsal-fin height 16-20; total bars on caudal fin 8-10, usually 4 bars on upper caudal-fin lobe, 3 on lobe itself and one at lobe base; broad red band on lower caudal-fin lobe, covering up to 5 or 6 red bars (only partly visible along the outer, ventral fin margin in fresh fish, bars may become more visible in preserved fish), but are usually not retained on preserved fish, apart from some traces of bars and dark pigmentation at the lower lobe fin tip; single mid-lateral body stripe running through eye, red from snout tip to eye and yellow from behind eye to caudal-fin base, not retained on preserved fish; first dorsal-fin tip pale; barbels white; body red above lateral line, body and head white laterally, with red or rose dots or blotches, ventral side of head and belly white; body uniformly pale brown in preserved fish; first minute dorsal-fin spine frequently dark pigmented forming small spot at fin origin, often distinct from above in preserved fish.

Distribution. Mozambique to Somalia, Madagascar, Red Sea, SW India, Sri Lanka, NW Australia, N Australia (Arafura Sea).

Remarks. Table 2 shows the morphometric and meristic data of the currently known 28 specimens of $U$. margarethae from the western Indian Ocean. The exclusion of the formerly misidentified specimen of $U$. randalli and inclusion of three additional specimens from Mafia Island and Sri Lanka affected the ranges of seven morphometric and two meristic characters, four of them being diagnostically important (Table 2).

No photographs of fresh fish are available for $U p$ eneus margarethae from areas other than Mozambique and due to indications of morphological variation among geographically well-separated populations, Uiblein and Heemstra (2010) restricted the selection of type specimens to the East African coast and Madagascar.

The second and third principal components of the PCA conducted in the current study allowed us to separate $U$. margarethae from the SW Indian Ocean, the Red Sea, and S-India/Sri Lanka (Fig. 3) Accordingly, the four specimens from SW India and Sri Lanka differ in a combination of several characters, including eye size, length of anal-fin base, second dorsal fin height, maximum head depth and interdorsal distance from nearly all others; and the two Red Sea specimens dif-

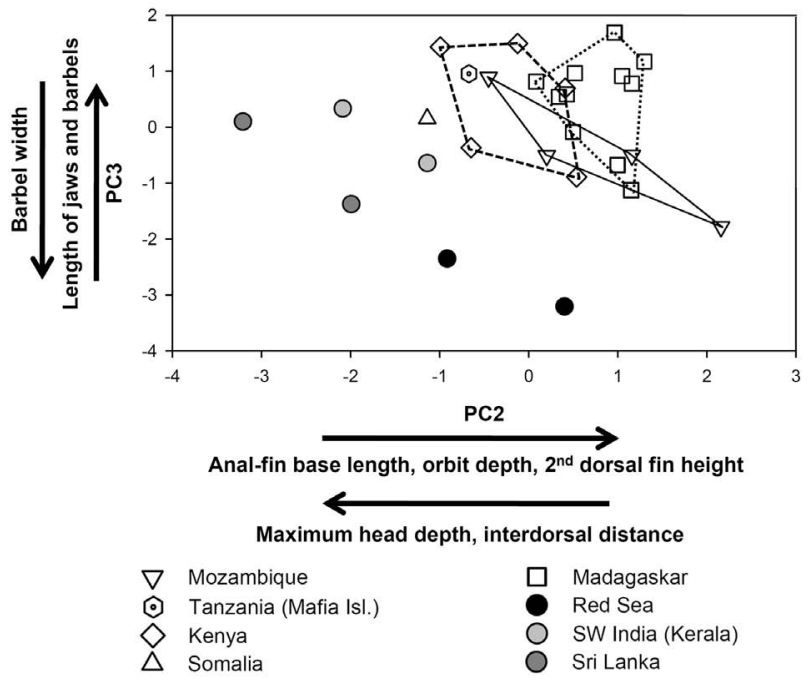

Fig. 3. - Scores of the second and third axis of Principal Component Analysis based on 40 morphometric characters in 28 Upeneus margarethae from different areas in the western Indian Ocean, with trends for the highest contributing characters indicated by arrows.

fer in the combination of jaw length, barbel length and barbel width from the others. However, the percentage of total variance explained by the second and third principal components is relatively low (14 and 9\% respectively).

Larger data sets with more specimens would be required to examine these distinctions more broadly and to better contrast morphological variation within populations with differences among populations at various geographical scales (Uiblein and Winkler, 1994).

Like its close relative $U$. randalli n. sp., U. margarethae is a small-sized goatfish species. It attains $11 \mathrm{~cm}$ SL; depth 8-50 m.

\section{DISCUSSION}

This study provides further evidence of the high diversity among goatfishes of the western Indian Ocean region. The discovery of another species of the genus Upeneus in the Persian Gulf, in addition to U. oligospilus (cf. Uiblein and Heemstra, 2010), indicates that this area has been insufficiently studied and may be biogeographically distinct (see also Ghanbarifardi and Malek, 2009). Due to the lack of data from adjacent areas and the complex geological history of this part of the Western Indian Ocean (e.g. Santini and Winterbottom, 2002), it remains unclear to us whether $U$. oligospilus and $U$. randalli should be considered as strictly endemic to the Persian Gulf.

The co-occurring Upeneus randalli $\mathrm{n}$. sp. and $U$. oligospilus differ from each other and from their close relatives, U. margarethae and U. tragula, in their caudal-fin colour patterns, including the number and form of bars on the caudal-fin lobes. Conspicuous, contrasting colour patterns may have certain functions related to predator avoidance and/or social communication. 
For instance, Uiblein and Nielsen (2005) found support for both functions when they studied the formation of contrasting eye-spots or ocelli on the dorsal fins of the ophidiid genus Neobythites and related this evidence to the high diversity found in this genus, which has over 50 currently known species.

The genus Upeneus is characterized by a highly modifiable body form that allows colour-independent distinction among species and populations, as reported in a comparative morphological study of the three goatfish species $U$. sulphureus, $U$. sundaicus, and U. tragula from Hainan Island, South China Sea (Uiblein et al., 1998). Since coloration fades away after death and may be completely lost during preservation, a thorough analysis of body form characters greatly facilitates identifying collected material, and also provides information on functional relationships between co-occurring populations of different species and habitat use as well as small-scale geographic differentiation patterns (Uiblein et al., 1998). Our multivariate analysis of geographical variation in morphometric characters of $U$. margarethae substantiates these earlier findings. Apart from differences among geographically well separated areas, more closely connected populations like those from the SW-Indian Ocean (Fig. 3) may also differ from each other considerably and hence deserve to be studied in detail in terms of micro-geographic phenotypic and genetic differentiation.

\section{ACKNOWLEDGEMENTS}

For the loan of collection material and/or making collection visits by the first author possible we thank Mark McGrouther, John Paxton and Amanda Hay (AMS), Jack Randall, Lori O'Hara, and Arnold Suzumoto (BPBM), and Peter R. Møller, Jørgen G. Nielsen, and Tammes Menne (ZMUC). Fernando Bordes assisted in the preparation of the Spanish abstract and keywords. The first author thanks the South African Institute for Aquatic Biodiversity and the Nansen Programme of the Center for Development
Cooperation in Fisheries at the Institute of Marine Research (IMR), Bergen, for travel support. We thank Gerri Allen and two anonymous referees for constructive comments.

\section{REFERENCES}

Bauchot, M.-L. and G. Bianchi. - 1984. Guide des Poissons Commerciaux de Madagascar. FAO species identification sheets for fishery purposes. Food and Agriculture Organization of the United Nations, Rome. (in French).

Fischer, W., I. Sousa, C. Silva, A. de Freitas, J.M. Putiers, W. Schneider, T.C. Borges, J.P. Feral and A. Massinga. - 1990. Guia de Campo das Espécies Comerciais Marinhas e de águas Salobras de Moçambique. FAO species identification sheets for fishery purposes. Food and Agriculture Organization of the United Nations, Rome. (in Portuguese).

Ghanbarifardi, M. and M. Malek. - 2009. Distribution, diversity, and abundance of rocky intertidal fishes in the Persian Gulf and Gulf of Oman, Iran. Mar. Biol. Res., 5(5): 496-502.

Randall, J.E. and E. Heemstra. - 2009. Three new goatfishes of the genus Parupeneus from the Western Indian Ocean, with resurrection of $P$. seychellensis. Smithiana Bull., 10: 37-50.

Randall, J.E. and D.R. King. - 2009. Parupeneus fraserorum, a new species of goatfish (Perciformes: Mullidae) from South Africa and Madagascar. Smithiana Bull., 10: 31-35.

Santini, F. and R. Winterbottom. - 2002. Historical biogeography of Indo-western Pacific coral reef biota: is the Indoneasian region a centre of origin? J. Biogeogr., 29: 189-205.

Uiblein, F. and P.C. Heemstra. - 2010. A taxonomic review of the Western Indian goatfishes of the genus Upeneus (Family Mullidae) with descriptions of four new species. Smithiana Bull., 11: 35-71.

Uiblein, F. and P.C. Heemstra. - 2011. A new goatfish, Upeneus seychellensis n. sp. (Mullidae), from the Seychelles Bank, with remarks on Upeneus guttatus and a key to Western Indian Ocean Upeneus species. Mar. Biol. Res., 7(7): in press.

Uiblein, F. and J.G. Nielsen. - 2005. Ocellus variation and possible functions in the genus Neobythites (Teleostei, Ophidiidae). Ichthyol. Res., 52(4): 364-372.

Uiblein, F. and H. Winkler. - 1994. Morphological variability among Vimba in Austrian waters: quantitative examination of a taxonomic and a functional hypothesis (Pisces: Cyprinidae). Senckenberg. Biol., 73: 57-65.

Uiblein, F, C. Köhler and M. C. Tian. - 1998. Quantitative examination of morphological variability among goatfishes of the genus Upeneus from the Malayan Province (Pisces: Perciformes: Mullidae). Senckenberg. marit., 28: 123-132.

Scient. ed.: M. Demestre.

Received April 29, 2010. Accepted November 30, 2010.

Published online June 7, 2010. 